\title{
HYPERCALCURIC RICKETS ASSOCIATED WITH RENAL TUBULAR DAMAGE
}

\author{
BY \\ C. E. DENT and M. FRIEDMAN \\ From the Medical Unit, University College Hospital, London
}

(RECEIVED FOR PUBLICATION OCTOBER 21, 1963)

Renal rickets or osteomalacia may be due to primary renal glomerular failure, usually with associated tubular damage, or to defects, often specific, in renal tubular function. Both types of rickets are characterized by being 'vitamin D resistant', that is, unresponsive to the $\mu \mathrm{g}$. doses of vitamin $\mathrm{D}$ that would rapidly cure classical vitamin D deficiency rickets. They always respond, however, to mg. doses of vitamin $D$, i.e. doses a thousand times larger than normal, some cases also requiring alkali therapy (Dent, Harper and Philpot, 1961).

Rickets due to primary renal glomerular failure is associated with a retention of urea, phosphate, creatinine, etc., which is due to the decrease in the glomerular filtration rate. Associated with this there is a marked decrease in the absorption of calcium from the gastro-intestinal tract, giving rise to a high faecal and low urinary calcium (Liu and Chu, 1943; Dent et al., 1961; Stanbury and Lumb, 1962). The exact nature of the defect in absorption is at present not known. Administration of vitamin D in large doses overcomes the defect in absorption with simultaneous healing of the rickets. This type of rickets may often be associated with radiological and histological changes of hyperparathyroidism or of osteosclerosis (Dent and Hodson, 1954; Crawford, Dent, Lucas, Martin and Nassim, 1954).

Albright, Butler and Bloomberg (1937) described the first carefully studied case of 'vitamin D resistant' rickets associated with a renal tubular defect, though they argued that the immediate cause of the bone disease was consequent on parathyroid overactivity, itself arising from a primary defect of intestinal calcium absorption. Their patient was a 16-year-old boy with a 14-year history of rickets who failed to respond to what had been considered adequate doses of vitamin D. He had hypophosphataemia, raised alkaline phosphatase and a normal blood urea. The typical clinical and radiological signs of rickets were present. He was given large doses of vitamin D (as calciferol) and eventually healing of the rickets was obtained by the administration of 450,000 i.u. $(11 \cdot 25 \mathrm{mg}$.) of the vitamin $\mathrm{D}$ a day.

Since that time an increasing number of additional types of renal tubular rickets have been described, under a bewildering variety of names. Dent (1952) presented a new classification of tubular rickets based on the various combinations of renal tubular defects. He recognized six subgroups which he called Type I-VI, all of which were similar to each other in having a high renal clearance for phosphate, but differed from each other in the extent of additional tubular defects. Thus in Type I rickets there is an isolated defect for the reabsorption of phosphate. In Type II in addition there is glycosuria. In Type III glycosuria and aminoaciduria are present. Type IV shows glycosuria, aminoaciduria and a defect in the tubular reabsorption of potassium and an inability to acidify the urine. Types $\mathrm{V}$ and VI show a renal loss of potassium together with an inability to acidify the urine and a defect in ammonia production. Types I-IV were often hereditary (Dent and Harris, 1956), whereas Types V and VI were originally thought to be always acquired. Clearly hereditary cases have, however, since been described (Schreiner, Smith and Kyle, 1953). Similar classifications have been suggested by others (Fanconi and Girardet, 1952; Jackson and Linder, 1953; Stanbury, 1958; Fraser and Salter, 1958).

The occurrence of isolated tubular abnormalities or the combination of a number of abnormalities is of great theoretical importance to our understanding of the normal functions of the tubule. Hence the discovery of additional types of renal tubular rickets, and the characterization of these abnormalities is of some importance. Over the last four years we have been following two patients with 'renal rickets' in whom there appears to be a specific renal tubular defect for the reabsorption of phosphate, calcium, amino acids and protein. Two apparently similar cases have recently been reported in France by Gentil, Habib, Le Tan Vinh, Colin, 


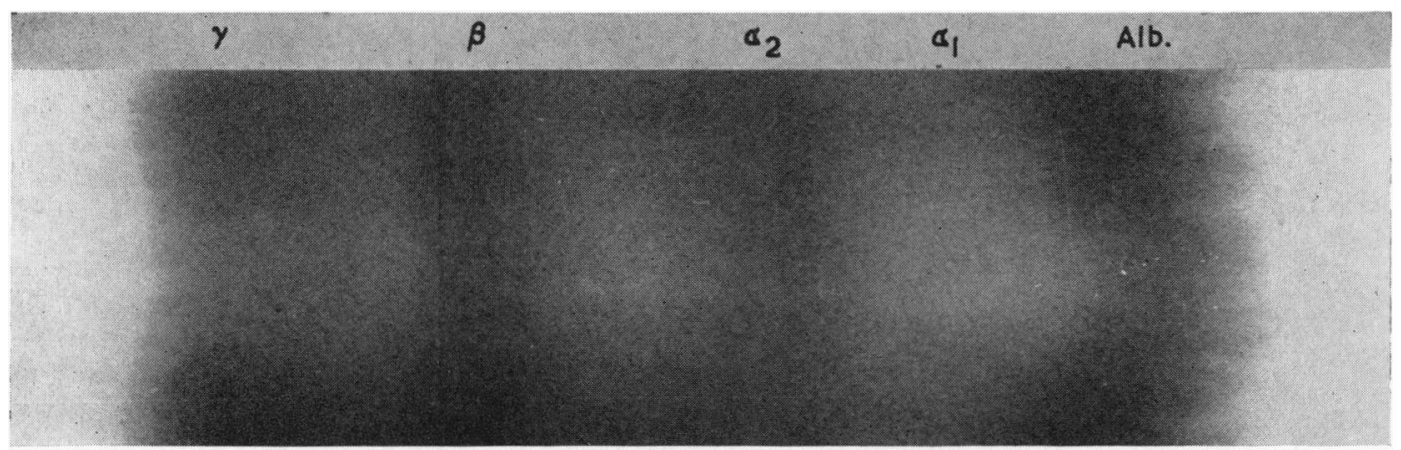

FIG. 1a.

FIG. 1.-Paper electrophoretic strips of urinary proteins. (a) Case 1: note that the albumin band is not the predominating one, $\alpha_{2}$ and $\boldsymbol{\beta}$ globulins appear of equal strength but are actually present in greater amounts as they take the stain less strongly. (b) $\mathbf{A}$ patient with a renal glomerular osteodystrophy. Albumin is the main band although $\alpha_{2}$ and $\beta$ migrating substances are also present.

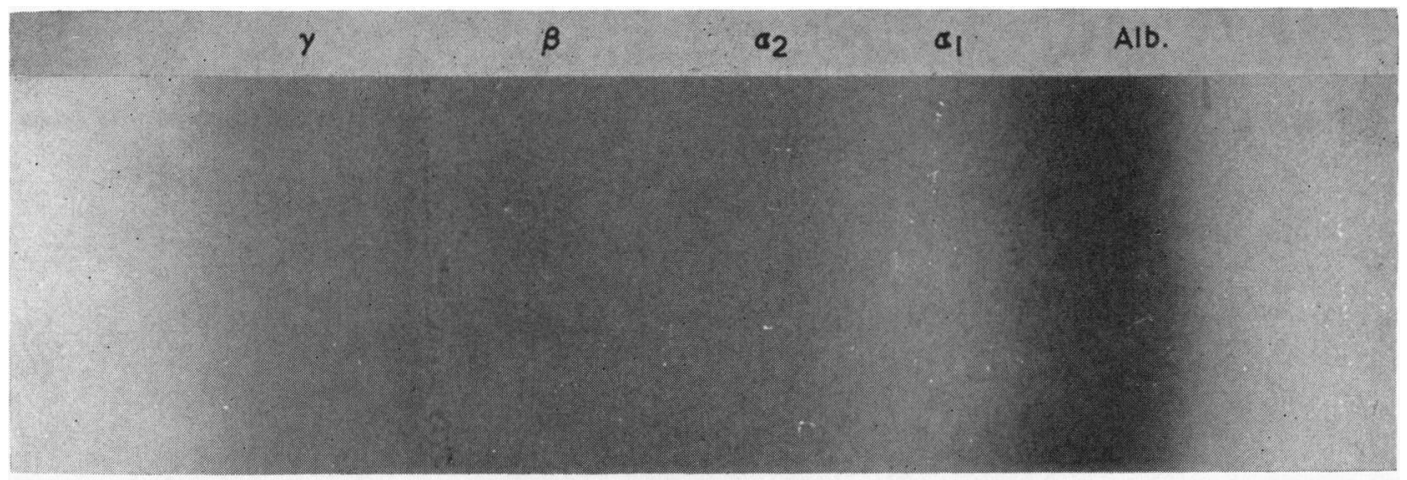

FIG. 1b.

Gabilan, Courtecuisse, Alagille and Lelong (1962). We are unaware of any other descriptions of this disease.

\section{Case Reports}

Case 1. Anthony B., a male child born in 1953 of unrelated parents. Weight at birth was $4 \cdot 8 \mathrm{~kg}$. after a full-term normal delivery. He passed the normal milestones. He received cod liver oil supplements until the age of 2 years. He was apparently perfectly healthy, except for frequent upper respiratory tract infections, until the age of 5 years. At this time he was noticed to have some difficulty in walking and complained of pain in the right knee and both elbows. In July 1959, at the age of $5 \frac{1}{2}$ years, he was admitted to another hospital for investigation. Examination at this time was normal except for a slight valgus deformity of the ankles. Radiographs showed typical changes of florid rickets in the hands and knees. Investigations confirmed the biochemical features of rickets, the serum calcium was $9.8 \mathrm{mg} . / 100 \mathrm{ml}$. and the phosphorus $2.8 \mathrm{mg} . / 100 \mathrm{ml}$., with an alkaline phosphatase of $61 \mathrm{King}$ Armstrong units. However, the 24-hour urinary calcium was $260 \mathrm{mg}$., plasma sodium $132 \mathrm{mEq} / \mathrm{l}$, potassium $4.8 \mathrm{mEq} / \mathrm{l}$., chloride $107 \mathrm{mEq} / \mathrm{l}$. and bicarbonate $19 \mathrm{mEq} / \mathrm{l}$. The urine contained a moderate amount of protein, a few pus cells and granular casts. Plasma urea was $21 \mathrm{mg} . / 100 \mathrm{ml}$. There was no evidence of nephrocalcinosis. In view of the association of rickets with hypercalcuria and a low plasma bicarbonate, a diagnosis of renal tubular acidosis was made. He was treated with 5,000 i.u. of vitamin D daily and small doses of sodium and potassium citrate. Radiographs showed signs of healing of the rickets. In May 1960 vitamin D was discontinued, but he continued to take sodium bicarbonate $2 \mathrm{~g}$. four times a day.

In November 1960 he was referred to the metabolic ward at U.C.H. and was under the care of one of us (C.E.D.). The most striking physical sign was his shortness of stature. His height was $114 \mathrm{~cm}$. which was just below 3rd percentile. He had mild bowing of both femurs and a slight genu valgus. His head showed much frontal bossing. The rest of the examination was normal.

Metabolic Studies. Plasma calcium $9.5 \mathrm{mg} . / 100 \mathrm{ml}$; specific gravity of plasma $1026-7$; phosphorus $2.4 \mathrm{mg}$./ $100 \mathrm{ml}$.; alkaline phosphatase $55 \mathrm{~K}-\mathrm{A}$ units; 24-hr. urinary excretion of calcium $314 \mathrm{mg}$.; plasma sodium $139 \mathrm{mEq} / 1$., potassium $3.8 \mathrm{mEq} / 1$., chloride $107 \mathrm{mEq} / \mathrm{l}$., bicarbonate $21.5 \mathrm{mEq} / \mathrm{l}$. Plasma total $\mathrm{CO}_{2} \quad 26 \cdot 8$ $\mathrm{mM} / \mathrm{l}$. Serum protein electrophoretic strip normal; the urine contained a trace of protein which was shown by electrophoresis (Dr. F. V. Flynn) to be 'tubular' protein (Fig. 1a). Glucose was absent. Maximum urinary 


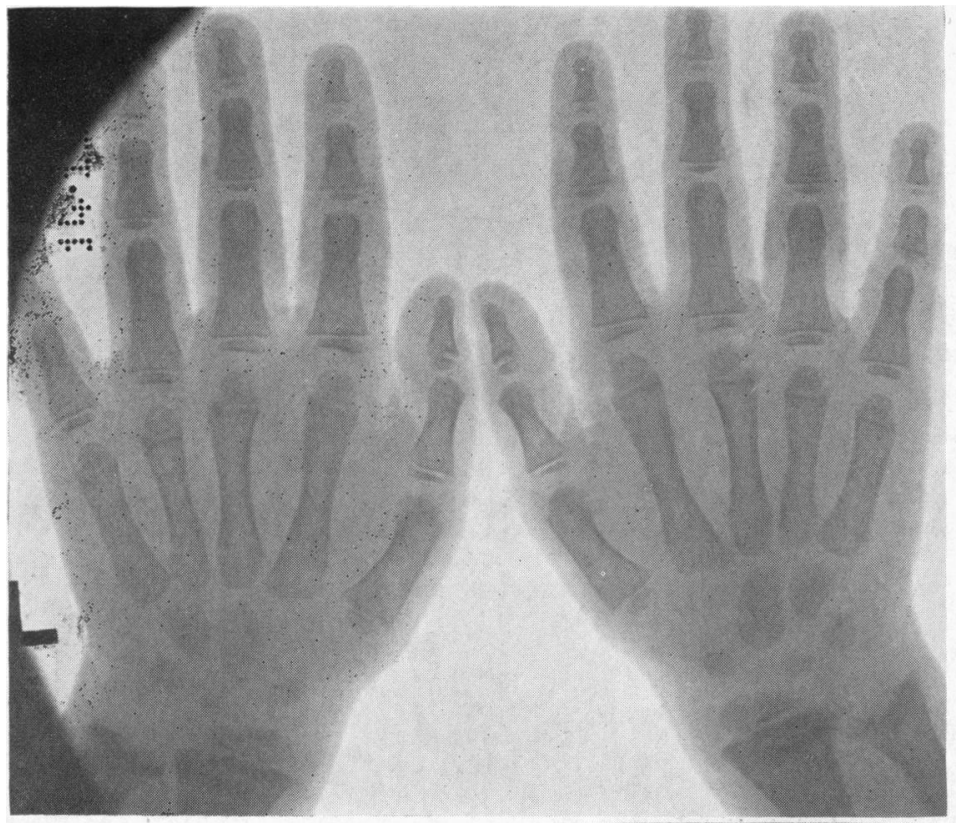

FIG. 2.-Bone radiographs of Case 1. (a) Wrists and (b) knees, November 10 , 1960. A recent early rickets is visible as well as the signs of healing from treatment given elsewhere from July 1960 to May 1961. No parathyroid changes are visible on the phalanges.

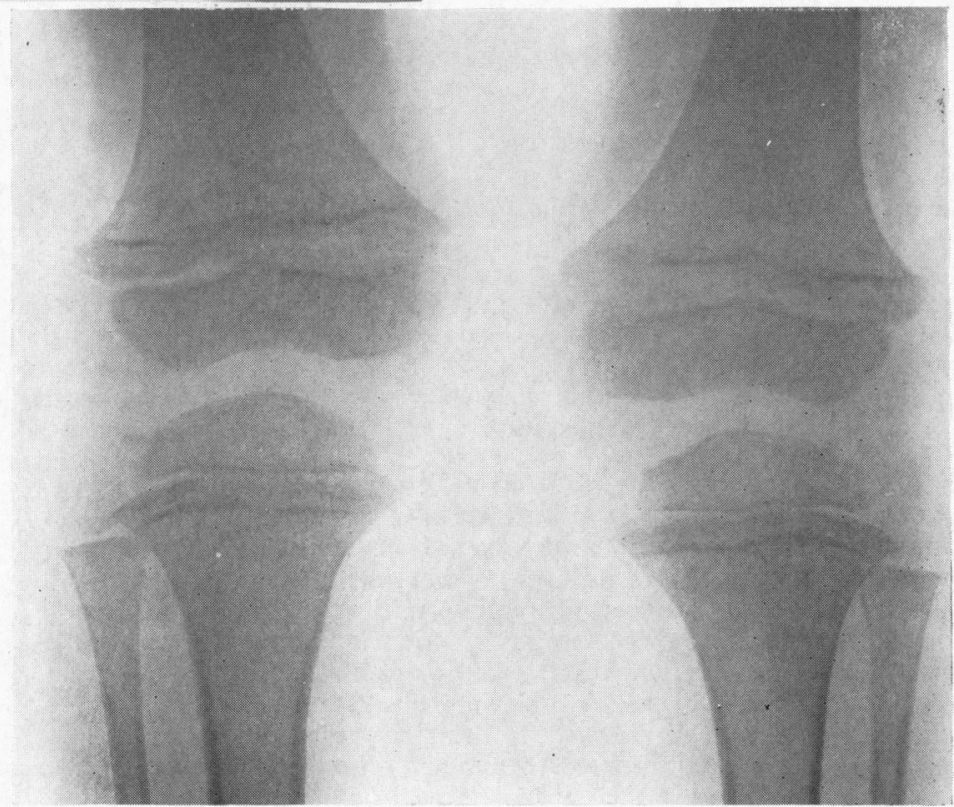

concentration, sp. gr. 1020. Plasma urea $21 \mathrm{mg} . / 100 \mathrm{ml}$. Urea clearance $73 \%$. Creatinine clearance (uncorrected) $46 \mathrm{ml} . / \mathrm{min}$. Following the administration of $2.5 \mathrm{~g}$. of ammonium chloride the urine $p H$ fell to $5 \cdot 18$ (normal below 5.30). On this test the output of ammonia was $46 \cdot 3 \mu \mathrm{Eq} / \mathrm{min}$. (normal 33-75), with a titratable acidity of $30.9 \mu \mathrm{Eq} / \mathrm{min}$. (normal 25-60). Total hydrogen ion concentration was $80.7 \mu \mathrm{Eq} / \mathrm{min}$. (normal 60-124). A six-day stool collection contained $2 \cdot 3 \mathrm{~g}$. fat per day which represented an absorption of $97 \%$ of the administered dietary fat. The amino acid chromatogram showed a moderate aminoaciduria with a 'central cluster' pattern of low molecular weight amino acids plus histidine, lysine, arginine, ornithine and cystine. Radiographs of the wrists and knees showed changes of partially healed rickets (Fig. 2a and b). The kidney size was normal.

Soon after admission his sodium bicarbonate was discontinued. This had no effect on the urine calcium which remained persistently above $300 \mathrm{mg}$./day. 
FIG. 3a and b.- Same bones as $2 \mathrm{a}$ and $\mathrm{b}$ (July 22, 1963) showing the excellent healing on treatment.
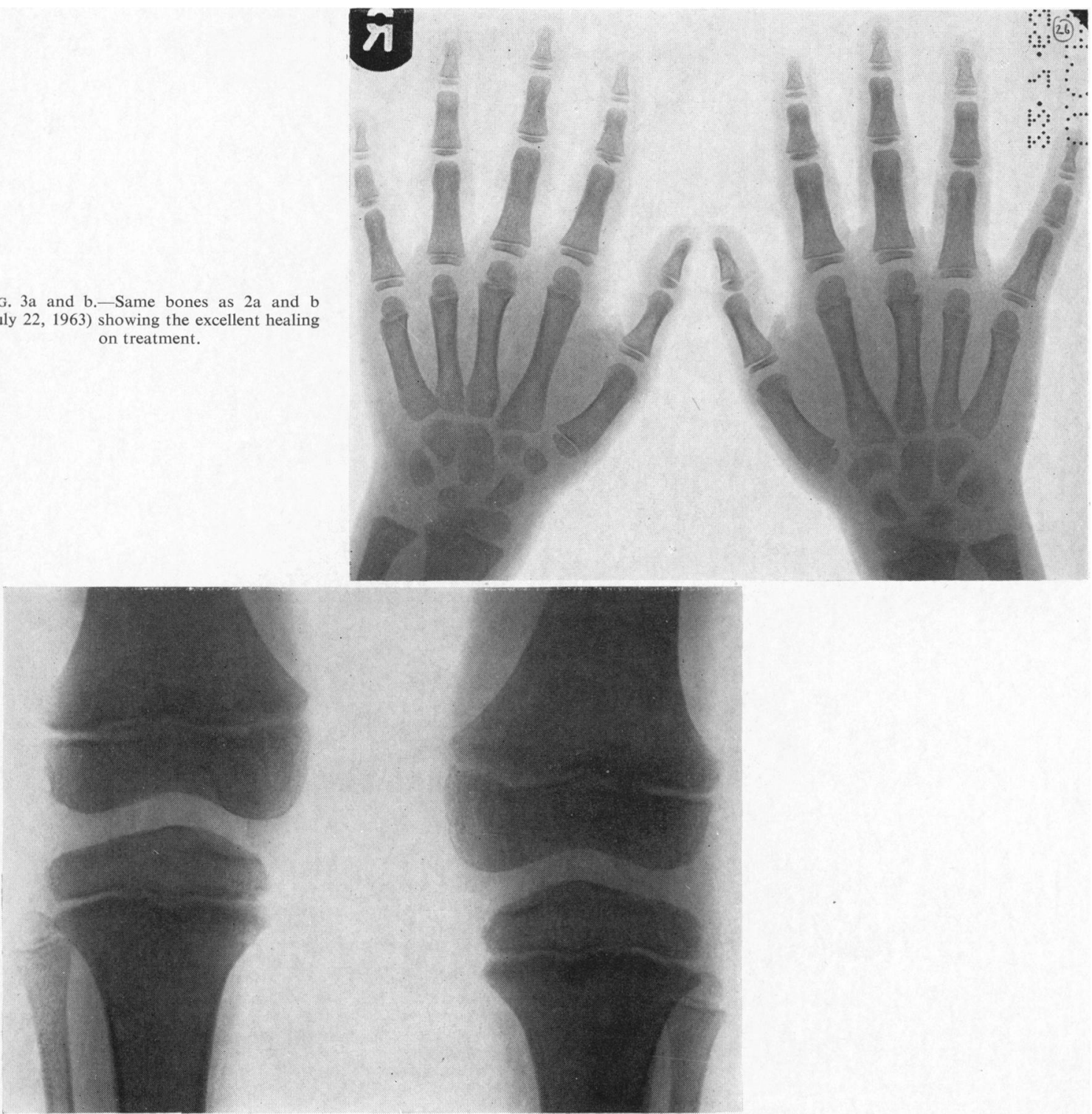

Calcium and phosphorus balances were carried out (Fig. 4). He was put on a moderately high calcium intake of $1330 \mathrm{mg}$. daily, with no added vitamin $D$. This showed a positive calcium balance of $180 \mathrm{mg}$. per day which was low for his age. Tests were carried out on three further six-day periods after the addition of 2000 i.u. $\left(50 \mu \mathrm{g}\right.$.) vitamin $D_{2}$ daily. This produced a positive calcium balance of $240 \mathrm{mg}$. per day. The dose of vitamin $D_{2}$ was then increased to $0.25 \mathrm{mg}$. daily $(10,000$ i.u.) and determinations were made over two further six-day periods which showed a rise in the positive balance to $360 \mathrm{mg}$. a day. However, on this dose of vitamin $\mathrm{D}$ the urine calcium rose to $450 \mathrm{mg} . / 24 \mathrm{hr}$. During this time there was a steady fall in alkaline phosphatase to $40 \mathrm{~K}-\mathrm{A}$ units and a most encouraging rise in the plasma phosphorus to $4.2 \mathrm{mg} . / 100 \mathrm{ml}$. Because of the striking hypercalcuria we added $1 \mathrm{~g}$. phosphorus, as disodium monohydrogen phosphate, to his intake daily, leaving his dietary intake and vitamin $\mathrm{D}$ dosage unchanged. This did not decrease the calcium output in the urine appreciably as we have found in many other patients with hypercalcuria (unpublished data), but produced an extremely large rise in the urinary phosphate excretion to $1500 \mathrm{mg}$. a day. The additional phosphate 


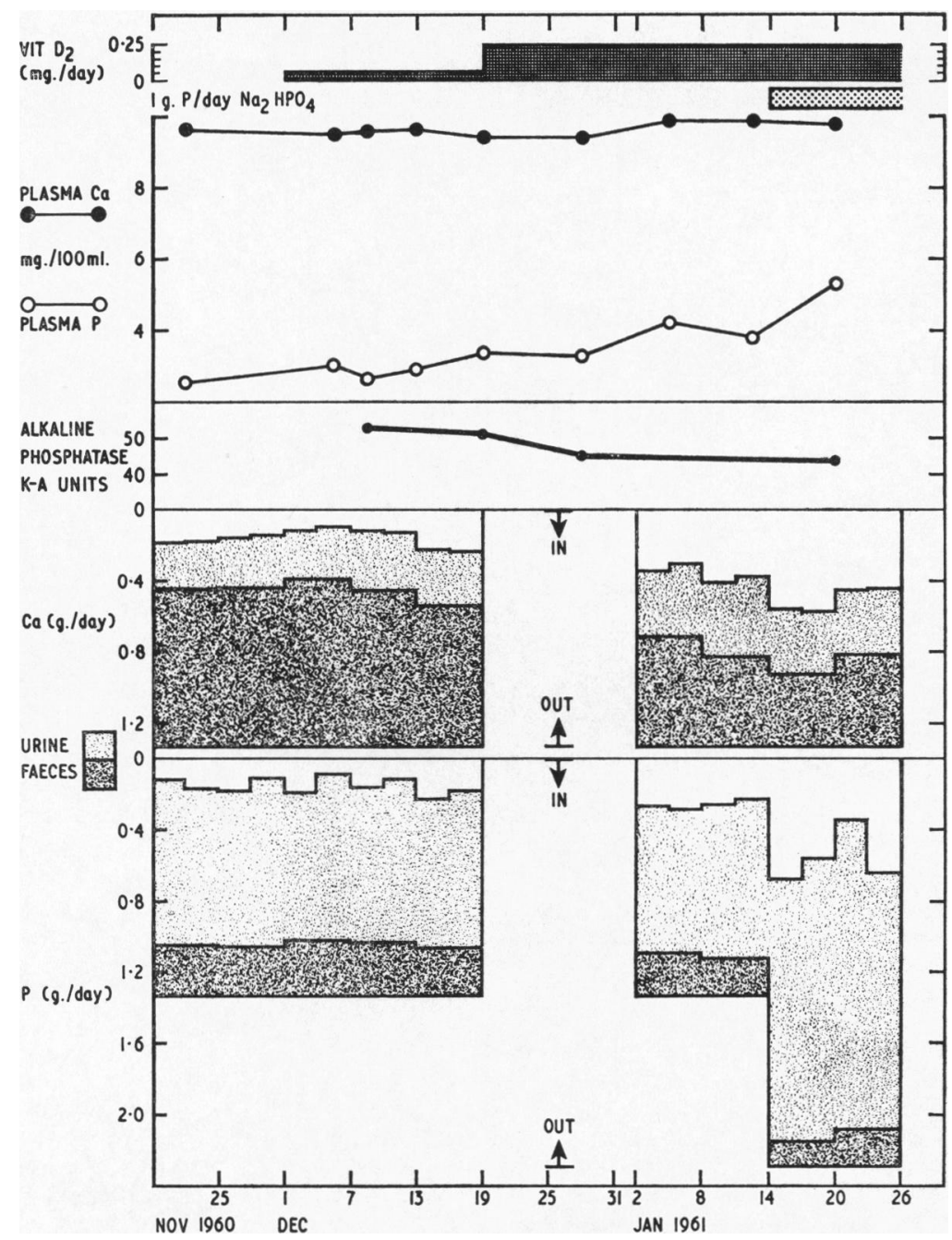

Fig. 4.-Metabolic balance data from Case 1 (Anthony B.). The balance data plotted in the conventional fashion (Reifenstein, Albright and Wells, 1945). The intake of calcium and phosphorus is measured downwards from the zero line. The output of faecal and urinary calcium and phosphorus is measured upwards. The clear space below the zero line represents the positive balance and therefore the retention of these substances in the body. Biochemical determinations and metabolic balances were done as described previously (Dent $e t$ al., 1961). The study consists of two six-day control periods, three periods on $0.05 \mathrm{mg}$. vitamin $D_{2}$ daily, two periods on $0.25 \mathrm{mg}$. vitamin $D_{2}$ daily, followed by two periods with added $\mathrm{Na}_{2} \mathrm{HPO}_{4}$. Note the normal absorption of calcium and phosphorus during the control periods. The vitamin $\mathbf{D}$ has increased the absorption of calcium and altered the partition of urinary and faecal calcium, in addition to increasing calcium retention. There is a rise in plasma phosphorus with vitamin $\mathrm{D}$, which rises still further when the phosphorus intake is increased.

was presumed to be an unsatisfactory form of therapy, because of the increased danger of stone formation, and was discontinued after the completion of the balance studies.

Progress. Since 1960 we have been treating him with $0.25 \mathrm{mg}$. of vitamin $D_{2}$ (calciferol) on alternate days. On this reduced dose of vitamin $\mathrm{D}_{2}$ he has continued to have a marked hypercalcuria with urinary calcium varying between 320 and $550 \mathrm{mg}$. $/ 24 \mathrm{hr}$. On this dose there has been complete radiological and clinical healing of his rickets (see Fig. 3a and b). Over the last two years his alkaline phosphatase has fallen from 40 to $30 \mathrm{~K}$-A units. His plasma phosphorus has remained between $3 \cdot 2$ and $4.0 \mathrm{mg} . / 100 \mathrm{ml}$. (Fig. 5). His plasma calcium has consistently remained below $10 \cdot 2 \mathrm{mg}$. $/ 100 \mathrm{ml}$. Electrophoresis of his urine still shows a typical tubular proteinuria. His mild aminoaciduria has also persisted.

$\mathrm{He}$ bas been very well and active throughout the follow-up period. Except for slight bowing of his 


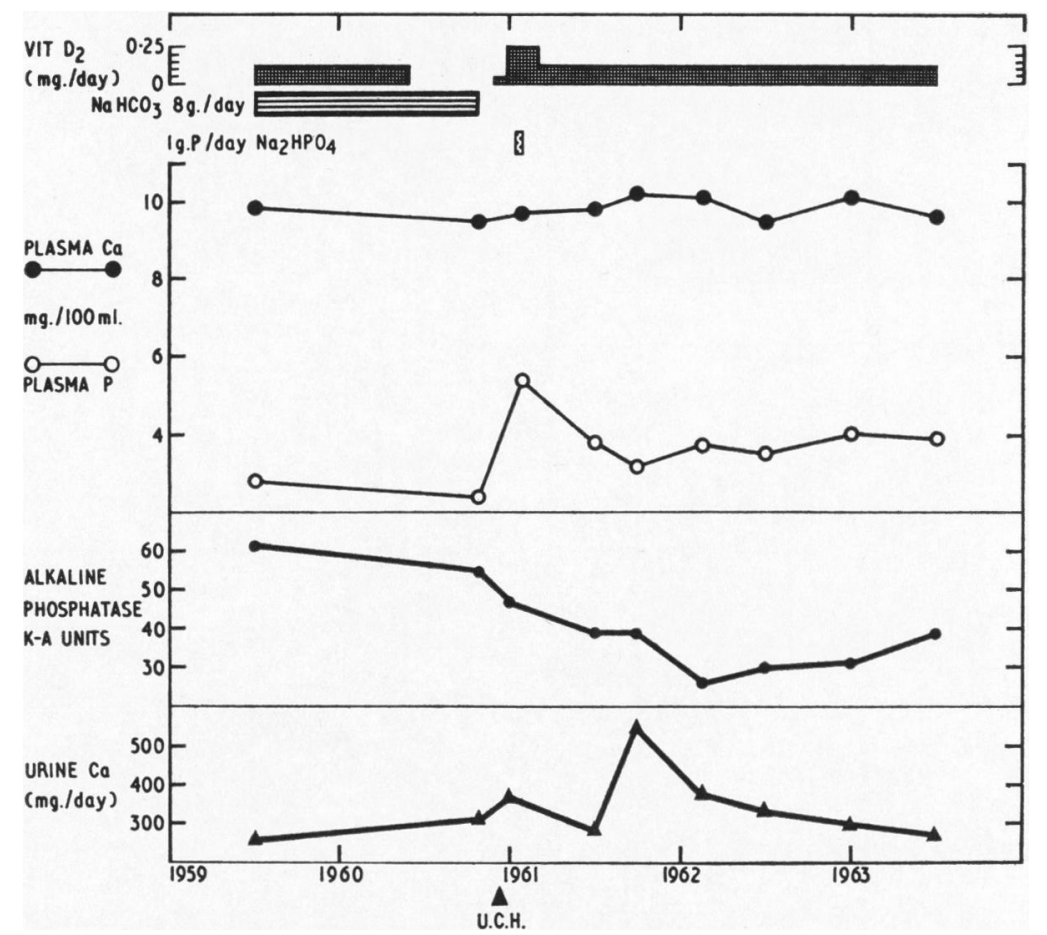

Fig. 5.-Biochemical data on Case 1 (Anthony B.) over the four-year follow-up period. His plasma phosphorus has remained low-normal for a boy of his age. Throughout the follow-up period his urine calcium has been persistently raised; this is probably partly due to a vitamin $\mathbf{D}$ effect, but his urinary calcium was raised before vitamin $\mathrm{D}$ was started.

femurs, there is no evidence of bony deformity. However, he has remained below the third percentile for height.

Case 2. Denis N. He was born prematurely, weighing $2.8 \mathrm{~kg}$., in 1940, of normal and unrelated parents. At the age of 8 weeks he was admitted to hospital because of failure to thrive. Urine examination was normal. $\mathrm{He}$ was discharged from hospital at the age of 6 months weighing $4.4 \mathrm{~kg}$. No specific diagnosis was made at the time. He received cod liver oil and orange juice supplements. He walked at 1 year of age, soon after which he was noticed to have some bowing of his legs. At the age of $2 \frac{1}{2}$ years he was admitted to hospital with active rickets, and found to be very retarded in growth. He was given vitamin $\mathrm{D}$, and the rickets healed in four months. From this time until the age of 5 years he was kept off his feet. In 1955 he was found to have protein in his urine. Urea clearance and intravenous pyelogram were normal.

At the age of 10 years the urea clearance was $55 \%$ of normal and the blood urea was $47 \mathrm{mg} . / 100 \mathrm{ml}$. The urine contained protein and the plasma calcium and phosphorus were normal.

At the age of 12 he was noted to be mentally backward and his intelligence quotient was estimated at 65 . He was found to have frontal bossing, a slight rachitic rosary, enlarged epiphyses at the knees, ankles, elbows and wrists. Radiographs showed no signs of active rickets.

At the age of 15 he complained of thirst and tiredness. He was admitted to his local hospital, where his blood urea was found to be $174 \mathrm{mg}$. $/ 100 \mathrm{ml}$. Blood pressure was $100 / 70 \mathrm{~mm} . \mathrm{Hg}$; fundi were normal. He was treated with a low protein diet and his blood urea fell to $33 \mathrm{mg}$./ $100 \mathrm{ml}$. The cause of this episode of uraemia is not apparent, but was probably pre-renal in origin. The possibility also exists that he may have been given a large dose of vitamin D by one or other of his doctors, and that this episode may have been due to vitamin $D$ intoxication.

In 1958 at the age of 18 he was referred to the metabolic ward of U.C.H. for further investigation. At this time he was found to be mentally retarded. He was unable to give a satisfactory history due to an extremely poor memory for past events. He had no specific complaints at the time. He passed urine three times a day and had no nocturia. There was no dysuria, and he was not thirsty. His mother and father were both well and he had one female sib aged 10 who was well. There was no history of renal disease in the family. His height was $4 \mathrm{ft} .10 \frac{1}{2}$ in. (148 cm.). Crown-pubis height $30 \frac{1}{2}$ in (77 cm.). Pubis-heel height $28 \frac{1}{2}$ in. $(72 \mathrm{~cm}$.). Span 58 in. (147 cm.). There was no bony tenderness. He had slight knock knees and marked frontal bossing. Blood pressure was $100 / 70 \mathrm{~mm} . \mathrm{Hg}$. Fundi were normal. His 


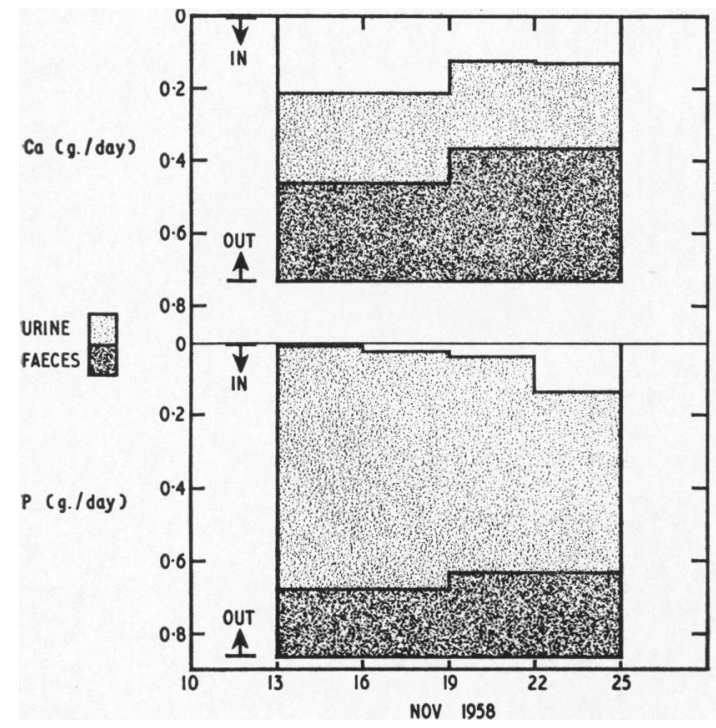

Fig. 6.-Metabolic balance data from Case 2 (Denis N.). The balance data plotted in the conventional fashion. At this time he was not having any treatment. Note the extremely high absorption of both calcium and phosphorus from the gut and the high urinary calcium. $\mathrm{He}$ is in positive balance for both elements.

heart was not enlarged. He was dark skinned but had no pigmentation on the mucous membranes of his mouth.

Metabolic Studies. Plasma calcium 9.9 mg./100 ml.; phosphorus $2.7 \mathrm{mg} . / 100 \mathrm{ml}$; ; alkaline phosphatase 37 K-A units. Plasma sodium $138 \mathrm{mEq} / \mathrm{l}$., potassium 4.0 $\mathrm{mEq} / \mathrm{l}$., chloride $108 \mathrm{mEq} / \mathrm{l}$., bicarbonate $22 \mathrm{mEq} / \mathrm{l}$., total protein $7.7 \mathrm{~g} . / 100 \mathrm{ml}$., bilirubin $0.4 \mathrm{mg} . / 100 \mathrm{ml}$. Colloidal red negative. Cephalin cholesterol negative. Thymol turbidity 1 unit. Urea $30 \mathrm{mg} . / 100 \mathrm{ml}$. Maximum urinary concentration after water deprivation, sp.gr. 1028. Maximum urinary dilution after a water load, sp.gr. 1004, with good excretion of the administered water load. Urine contained an occasional pus cell, no red cells and was sterile on culture. Urine contained protein which on electrophoresis was typical of tubular proteinuria. Glucose was absent. 24-hr. urinary calcium was $232 \mathrm{mg}$. Urine amino acid chromatogram showed a "central cluster' pattern aminoaciduria.

RADIOGRAPHS. A review of a series of past radiographs showed that he had slight but definite radiological signs of rickets at the age of $2 \frac{1}{2}$ years. Since that time there have been no specific signs of active rickets or hyperparathyroidism. Radiographs of teeth are normal. Radiological bone age was estimated at 16-17 years when his chronological age was 18 . Intravenous pyelogram showed a good concentration of dye on both sides. Both kidneys were normal and equal in size. There was no evidence of obstruction to the outflow of urine. Calyceal pattern was normal.

An ammonium chloride test was performed to exclude a renal tubular acidosis. He was given $2 \mathrm{mEq} / \mathrm{kg}$. body

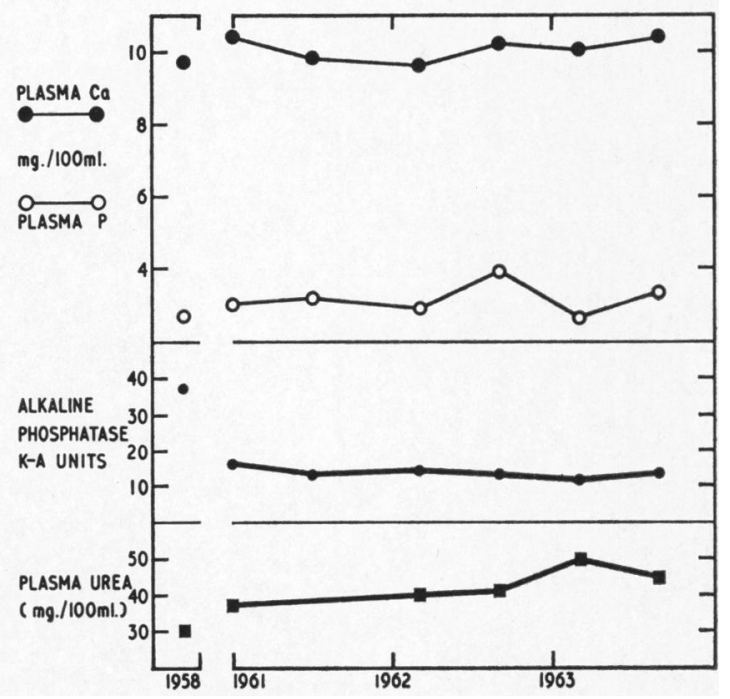

FIG. 7.-Follow-up biochemical data on Case 2 (Denis N.). Note the persistently low plasma phosphorus. After the first high reading in 1958, the alkaline phosphatase was at the upper limit of normal. Throughout this period he has had no treatment. He was not under our follow-up 1958-1961.

weight of ammonium chloride daily for four days. On the second day of the test his urine $p \mathrm{H}$ fell to $5 \cdot 2$ and his ammonia output rose to $53 \mathrm{mEq} / 24 \mathrm{hr}$. On the fourth day of the test the urine $p \mathrm{H}$ was 4.9 and the blood $p \mathrm{H}$ was $7 \cdot 39$.

His comparatively dark skin and a blood pressure that varied between $110 / 70$ and $95 / 60 \mathrm{~mm} . \mathrm{Hg}$. suggested the possibility of a sodium-losing defect. His renal conservation of sodium was therefore investigated, with the help of Dr. E. Ross, to determine whether he had a sodium-losing kidney. He was given $9-\alpha$-fluorohydrocortisone $10 \mathrm{mg}$. a day for two days. On this dosage there was a fall by one-third in his sodium output with a slight rise in his potassium. He was then given a low sodium intake of only $14 \mathrm{mEq} /$ day. On this régime his urine sodium fell from $185 \mathrm{mEq} /$ day to $12 \mathrm{mEq} /$ day. Both tests suggested normal renal conservation of sodium.

Calcium and phosphorus balances were performed on his normal dietary intake over two six-day periods (Fig. 6). These showed a positive calcium balance of $170 \mathrm{mg}$./day. There was exceedingly good calcium absorption from the gastro-intestinal tract. The urine calcium, however, was raised throughout at $240 \mathrm{mg}$./day.

He has been followed intermittently since 1958 and over this period has been extremely well. It appears that no general symptoms result from his renal tubular damage. He has had no therapy. $\mathrm{He}$ is at present (September 1963) working as a fitter's mate. He has no nocturia, thirst or urinary symptoms. His height is $5 \mathrm{ft}$. $(152 \mathrm{~cm}$.); blood pressure $110 / 70 \mathrm{~mm} . \mathrm{Hg}$.; plasma calcium $10.0 \mathrm{mg}$./ $100 \mathrm{ml}$.; plasma specific gravity 1029-30. Phosphorus has varied between 2.6 and $3.9 \mathrm{mg} . / 100 \mathrm{ml}$. Alkaline phosphatase $11 \mathrm{~K}-\mathrm{A}$ units. Urea $45 \mathrm{mg} . / 100 \mathrm{ml}$. (Fig. 7). 
Urinary calcium $325 \mathrm{mg} . / 24 \mathrm{hr}$. Electrophoresis of his urine still shows a typical tubular proteinuria.

\section{Discussion}

The cause of the rickets in these two patients presented us with a new problem. There was no evidence for classical vitamin $D$ deficient rickets. Both patients had been given adequate doses of vitamin $D$ supplements since birth, and the lack of response of Case 1 to 2,000 i.u. of vitamin D was also atypical of classical rickets. Furthermore in classical rickets the urinary excretion of calcium is very low (Nicolaysen, Eeg-Larsen and Malm, 1953). The finding of a much raised urinary excretion of calcium excludes this diagnosis.

There was no evidence of a malabsorption syndrome in either case. Neither patient had a history of diarrhoea or the passage of large bulky stools. There was no evidence of anaemia. Steatorrhoea was excluded by the finding of a normal fat excretion under balance conditions. The calcium balance, in both cases, showed good absorption of calcium from the gut. In rickets or osteomalacia due to a malabsorption syndrome the urinary excretion of calcium is very low, except in those very exceptional cases in which hyperparathyroidism supervenes due to the growth of an autonomous adenoma (Davies, Dent and Willcox, 1956).

Hypercalcuria and rickets do however occur in renal tubular acidosis. This diagnosis was clearly excluded, for both patients were able to handle an administered ammonium chloride load efficiently, the urine $p \mathrm{H}$ in both cases being reduced to below $5 \cdot 2$. The ammonia production and titratable acidity of the urine were normal. Case 1 was treated with sodium bicarbonate for over a year before coming to U.C.H.; this therapy had no effect on the urine calcium excretion which remained practically unchanged after discontinuing the sodium bicarbonate.

The age of presentation ( $5 \frac{1}{2}$ years) in Case 1 was unlike that of the common hereditary forms of 'resistant' rickets. These usually present at an earlier age, especially in boys who, furthermore, at least in the sex-linked form, show severer rickets than do girls. The absence of a family history was also against this diagnosis, although sporadic cases are known to occur (Dent and Harris, 1956; Winters, Graham, Williams, McFalls and Burnett, 1958; Burnett, Dent, Harper and Warland, 1964). Moreover, in the hereditary forms of vitamin D resistant rickets the calcium balance shows a high faecal and low urine calcium, and not a low faecal and raised urine calcium as in these two patients. Another unique feature in Case 1 , the only case with active rickets, is that the rickets healed with doses of vitamin D $(0.25 \mathrm{mg}$. or so) which would be quite ineffective in the other diseases.

A renal osteodystrophy of more usual kind was suspected at an early stage because of the presence of proteinuria. The absence of urea and creatinine retention, the normal clearances and normal kidney size radiologically, excluded primary chronic renal glomerular damage as a cause of the rickets. Electrophoresis of the urinary protein demonstrated the distinctive pattern that occurs in 'non-specific' renal tubular disorders (Cusworth and Dent, 1960) (Fig. 1a). This is characterized by relatively high contents of protein migrating as $\alpha_{2}$ and $\beta$ globulins (Butler and Flynn, 1958).

The relatively low plasma phosphorus can be explained on the basis of a defective tubular reabsorption of phosphorus and a consequent high renal clearance of phosphate. We believe that this, or more probably some closely associated tubular function, is the mechanism of causation in most other types of renal tubular rickets. Certainly in the presence of normal calcium absorption from the gut the original Albright theory that the low plasma phosphorus in such cases could be due to a secondary hyperparathyroidism from a 'tendency' to low plasma calcium from poor gut absorption is inapplicable here. Fig. 8 shows the effect of vitamin $D$ on the phosphate threshold in Case 1 (Anthony B.). It is of interest to note that increasing the dose of vitamin D increases the tubular reabsorption of phosphate, independent of phosphate intake. This effect is usually associated with healing of the rickets in this group of diseases.

In both cases there has been complete radiological healing of the rickets. However, we are very disappointed with the lack of progress of growth in stature. Both patients are below the third percentile for height. In a large group of vitamin resistant rickets (Dent, Type I), treated with large doses of vitamin $\mathrm{D}$, which we have been carefully following for some years, we have noticed a similar healing of the rickets associated with a lack of growth. Most of the patients remain below the third percentile and often fail to reach a socially acceptable height of 5 feet. This is particularly marked in the case of men, when it is, of course, more distressing than with women. At present the problem of dwarfism is the most pressing practical clinical problem in the treatment of this group of diseases, and the solution of this still eludes us. We seem to have no difficulty in curing the rickets and in preventing the development of deformities.

Also of interest is the mental retardation in Case 2. Our own unpublished data show that a significant 


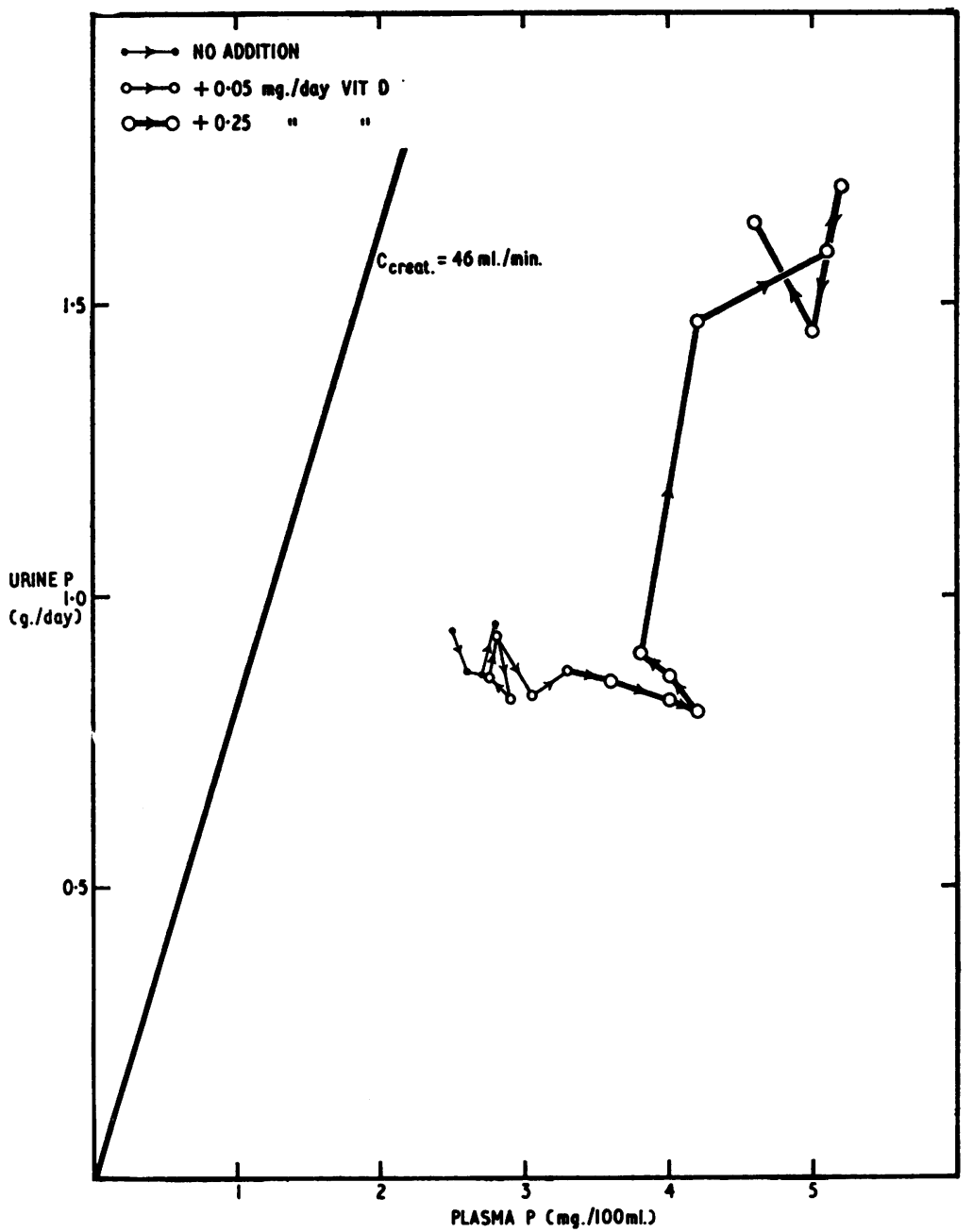

FIG. 8.-In this diagram we have plotted the early morning fasting plasma phosphorus of Case 1 (Anthony B.) against the 24-hour excretion of phosphorus in the urine on the same day. This gives an approximate guide to the renal phosphate threshold and thus to changes in the $\mathbf{T m}$ for phosphate. With increasing doses of vitamin $\mathbf{D}$ there is a shift to the right, indicating that the rise in plasma $\mathbf{P}$ was due to a raising of phosphate threshold, rather than to dietary or other factors.

The oblique line passing through the zero point shows the relation between urine and plasma creatinine assuming the clearance obtained. The corresponding relation for phosphate in a normal subject with the same clearance would be represented on our diagram by a line running parallel to the creatinine line, but cutting the abscissa at about $3.5 \mathrm{mg} . / 100 \mathrm{ml}$. Our patients' readings while on the high dose of vitamin D correspond roughly to such a line. The points obtained previously while on smaller doses were nearer to the creatinine line, indicating diminished renal tubular reabsorption of phosphate.

proportion of patients with congenital renal damage are mentally defective. The operative factor in these cases seems to be that the disease must be manifest very soon after birth. We presume that normal placental functions can protect the newborn baby who has defective kidneys but who is otherwise normal.

It appears, therefore, that both these patients have a limited defect of the renal tubules leading to a defective reabsorption of calcium, phosphorus, low molecular weight 'globulins' and amino acids without malabsorption of calcium from the gut. The aetiology of the defect is at present unknown. We think it could be acquired from the action of some environmental factor. Heavy metal poisoning may produce similar renal tubular damage, for instance, in the case of cadmium pigment workers (Kazantzis, Flynn, Spowage and Trott, 1963). Of special interest is that in the particular form of renal tubular damage, presumably due to copper, in Wilson's 
disease, there is also, as in our Cases 1 and 2, excessive absorption of calcium from the intestine (Morgan, Stewart, Lowe, Stowers and Johnstone, 1962). However, we were unable to obtain a history or to elicit the physical signs of any heavy metal poisoning which is known to produce this picture of renal tubular dysfunction. It is important to stress that our follow-up of Case 2 suggests that the prognosis for life in this disease is excellent, in contrast to most other syndromes with rickets and proteinuria.

\section{Summary}

Two cases of a rare form of renal tubular rickets are reported. The defect in the renal tubule only involves the reabsorption of phosphate, calcium, protein and amino acids. Both patients presented with clinical and radiological signs of rickets, hypercalcuria and tubular proteinuria. Radiological healing of the rickets has been obtained with only moderate doses of vitamin D. Both patients have exhibited much retardation in growth, remaining below the third percentile for height.

In view of the absence in both cases of a family history it may be that the renal tubular defect is acquired and not hereditary. Steatorrhoea and renal acidosis were excluded by the appropriate tests.

We wish to thank the nurses, dietitians and biochemists of the metabolic ward for their help during the in-patient admission and subsequent follow-up of these patients. We are most grateful to Dr. H. Jolly for referring Case 1 and to Dr. K. W. Lovel for referring Case 2.

\section{REFERENCES}

Albright, F., Butler, A. M. and Bloomberg, E. (1937). Rickets resistant to vitamin D therapy. Amer. J. Dis. Child., 54, 529.

Burnett, C. H., Dent, C. E., Harper, C. M. and Warland, B. J. (1964). Vitamin D resistant rickets (familial hypophosphatemia). A genetic analysis of twenty-four kindreds. Amer. J. Med., 36, 222.
Butler, E. A. and Flynn, F. V. (1958). The proteinuria of renal tubular disorders. Lancet, 2, 978.

Crawford, T., Dent, C. E., Lucas, P., Martin, N. H. and Nassim, J. R. (1954). Osteosclerosis associated with chronic renal failure. ibid., $2,981$.

Cusworth, D. C. and Dent, C. E. (1960). Inborn errors of tubular function. In Biology of Pyelonephritis. [Henry Ford Hospital International Symposium, 1959], ed. E. L. Quinn and E. H. Kass, p. 535. Little, Brown, Boston.

Davies, D. R., Dent, C. E. and Willcox, A. (1956). Hyperparathyroidism and steatorrhoea. Brit. med. J., $2,1133$.

Dent, C. E. (1952). Rickets and osteomalacia from renal tubule defects. J. Bone Jt Surg., 34B, 266.

- Harper, C. M. and Philpot, G. R. (1961). The treatment of renal-glomerular osteodystrophy. Quart. J. Med., 30, 1

- and Harris, H. (1956). Hereditary forms of rickets and osteomalacia. J. Bone Jt Surg., 38B, 204.

- and Hodson, C. J. (1954). Generalised softening of bone due to metabolic causes. II. Radiological changes associated with certain metabolic bone diseases. Brit. J. Radiol., n.s., 27, 605.

Fanconi, G. and Girardet, P. (1952). Familiärer persistierender Phosphatdiabetes mit D-vitamin-resistenter Rachitis. Helv. paediat. Acta, 7, 14.

Fraser, D. and Salter, R. B. (1958). The diagnosis and management of the various types of rickets. Pediat. Clin. N. Amer., May, 417.

Gentil, C., Habib, R., Le Tan Vinh, Colin, J., Gabilan, J. C., Courtecuisse, V., Alagille, D. and Lelong, M. (1962). Nanisme avec rachitisme, hypercalciurie et proteinurie. (Deux observations). Ann. Pédiat., 9, No. 17, p. 784.

Jackson, W. P. U. and Linder, G. C. (1953). Innate functional defects of the renal tubules, with particular reference to the Fanconi syndrome. Cases with retinitis pigmentosa. Quart.J. Med., 22, 133.

Kazantzis, G., Flynn, F. V., Spowage, J. S. and Trott, D. G. (1963). Renal tubular malfunction and pulmonary emphysema in cadmium pigment workers. ibid., 32, 165 .

Liu, S. H. and Chu, H. I. (1943). Studies of calcium and phosphorus metabolism with special reference to pathogenesis and effects of dihydrotachysterol (A.T.10) and iron. Medicine (Baltimore), 22, 103.

Morgan, H. G., Stewart, W. K., Lowe, K. G., Stowers, J. M. and Johnstone, J. H. (1962). Wilson's disease and the Fanconi syndrome. Quart. J. Med., 31, 361.

Nicolaysen, R., Eeg-Larsen, N. and Malm, O. J. (1953). Physiology of calcium metabolism. Physiol. Rev., 33, 424.

Reifenstein, E. C., Jr., Albright, F. and Wells, S. L. (1945). The accumulation, interpretation, and presentation of data pertaining to metabolic balances, notably those of calcium, phosphorus, and nitrogen. J. clin. Endocr., 5, 367.

Schreiner, G. E., Smith, L. H. and Kyle, L. H. (1953). Renal hyperchloraemia acidosis. Amer. J. Med., 15, 122.

Stanbury, S. W. (1958). Some aspects of disordered renal tubular function. Advanc. intern. Med., 9, 231.

- and Lumb, G. A. (1962). Metabolic studies of renal osteodystrophy. Medicine (Baltimore), 41, 1.

Winters, R. W., Graham, J. B., Williams, T. F., McFalls, V. W. and Burnett, C. H. (1958). A genetic study of familial hypophosphatemia with vitamin D resistant rickets, with a review of the literature. ibid., 37, 97. 